RESEARCH PAPER

\title{
Tobacco industry strategy to undermine tobacco control in Finland
}

\section{H Hiilamo}

Correspondence to:

Dr Heikki Hiilamo,

National Research and

Development Centre for

Welfare and Health,

Lintulahdenkuja 4, 00530

Helsinki, Finland;

heikki.hiilamo@stakes.fi

Received

26 November 2002

Accepted

9 September 2003

Objective: To identify and explain tobacco industry strategy in undermining tobacco control measures in Finland and results of these interferences in tobacco policy development during the 1980s and early 1990s.

Methods: Tobacco industry documents, which have been publicly available on the internet as a result of litigation in the USA, were analysed. Documents were sought by Finland and by names of organisations and tobacco control activists. Documents were accessed and assessed between September 2000 and November 2002. Tactics of the tobacco industry activities were categorised as presented by Saloojee and Dagli.

Results: The international tobacco companies utilised similar strategies in Finland as in other industrial markets to fight tobacco control and legislation, the health advocacy movement, and litigation. These activities slowed down the development and implementation of the Tobacco Act in Finland. However, despite the extensive pressure, the industry was not able to prevent the most progressive tobacco legislation in Europe from being passed and coming into force in Finland in 1977 and in 1995.

Conclusion: Denying the health hazards caused by tobacco-despite indisputable scientific evidencedecreased the credibility of the tobacco industry. Strategy of denial was falsely chosen, as health advocacy groups were active both in society and the parliamentary system. The strong influence of the tobacco industry may have in fact increased the visibility of tobacco control in Finland as the litigation process was also drawing attention to negative health effects of tobacco. Therefore the tobacco industry did not manage to convince public opinion. However, the tobacco industry did obtain experience in Finland in how to object to tobacco control measures.

$\mathrm{T}$ he globalisation of the world economy has brought into debate the influence of multinational companies in political processes and democracy. ${ }^{1-3}$ The multinationals have been criticised for undermining democracy with their economic power-that is, by affecting decision making through illegal or unethical means. Up to the mid 1990s there were hardly any data to show whether this actually occurred. The emergence of millions of pages of internal documents from the tobacco industry through US lawsuits changed the situation in $1998 .^{4-8}$

All industries try to encourage a regulatory framework that is favourable to their business, and there is nothing inherently undemocratic in doing so. The denial of health hazards and the attempts to corrupt scientific record puts the tobacco companies in a different position. One of the major advantages of the tobacco documents is that they allow us to trace and analyse the various ways in which the tobacco companies have tried to communicate their views on the health issue and thereby influence regulation.

Finland has been in the forefront of international progress on health promoting tobacco legislation. In 1961, parliament requested the government to take measures to reduce smoking and to consider legislative action. By the 1970s, pressure led to a strict Tobacco Act being passed in 1977. Early on, high taxes were imposed on tobacco products to cut down consumption. The first product liability case against the tobacco industry in Europe was brought in 1988. The revision of the Tobacco Act in 1995 introduced restrictions on smoking in the workplace and ensured the reduction of exposure to environmental tobacco smoke (ETS). The Act prohibited smoking at all work sites, and banned the sale of tobacco products to persons below 18 years and all forms of sales promotion. ETS was included in the Tobacco Act in 2000 as a carcinogenic substance. A year later, an amendment to the Act incorporated restaurants into the regulations.

The largest multinational tobacco companies in the world-Philip Morris (PM), British American Tobacco (BAT), and RJ Reynolds Tobacco Company (RJR) — have dominated the Finnish tobacco market during the past decades. Amer-Tupakka (Amer Tobacco, a licensed manufacturer of PM brands) controls about $75 \%$ of the market, British American Tobacco Nordic has a 15\% market share, and Altadis (originally privately owned by Rettig, then RJ Reynolds and then Seita) al0\% share. Amer-Tupakka has had a licence agreement with PM since 1961, and the licence is valid until the end of 2005 on the basis of the current agreement. Referring to the dominance of the US tobacco companies within the country, Finland has been described as the 51 st state in tobacco issues. ${ }^{9}$

As a hypothesis, we may assume that the regulatory framework in Finland has offered the tobacco industry almost laboratory-like circumstances to find out how tobacco companies can get along with comprehensive legislation and influence its development. Failure in the small Finnish market would hardly have much effect on international sales. Instead, experience gained in Finland could indicate to

\footnotetext{
Abbreviations: BAT, British American Tobacco; CCC, Central Chamber of Commerce; EEMA, Eastern Europe, the Middle East, and African countries; EPA, US Environmental Protection Agency; EU, European Union; ETS, environmental tobacco smoke; HBI, Healthy Buildings International; IFAQ, in-flight air quality test; NMA, National Manufacturers Association; PM, Philip Morris; RJR, RJ Reynolds Tobacco Company; SAK, Central Organisation of Finnish Trade Unions; TKL, Confederation of Finnish Industry and Employers
} 
the tobacco industry how to prevent threatening legislation elsewhere.

This article examines how global tobacco companies have tried to influence tobacco regulation in Finland, a small, but interesting market area due to its special features. The aim is not only to analyse the strategy of the industry, but also to estimate what kind of effects the tobacco companies have had on Finnish tobacco policies in the 1980s and early 1990s. The main question is: did the tobacco companies succeed in finding a successful strategy for undermining the development of tobacco control in Finland?

\section{MATERIALS AND METHOD}

The material for this article has been acquired by searching for tobacco industry documents from the databases available on the internet subsequent to the 1998 Master Settlement Agreement between the 46 US state attorneys general and the tobacco industry. ${ }^{10}$ Documents have been gathered mainly for lawsuits focusing on the activities of tobacco companies in the USA. Documents with a reference to Finland in most cases concern a wider market area-for example, the Nordic countries or EEMA (Eastern Europe, the Middle East and African countries). For this reason, the material is fragmented.

Documents concerning Finland were sought systematically by using search words such as "Finland", "Finnish", names of organisations related to Finland, Finnish publications (newspapers, magazines, etc), working groups (Egil group, Nordic Council), tactics (Whitecoats, Courteous Smokers Club Hu-Tu), companies (Amer-Tupakka, Rettig), cities (Helsinki, Tampere, Turku), and individuals. We searched for representatives of tobacco companies, tobacco activists, lawyers in tobacco litigation, politicians, and medical doctors (especially industry witnesses in tobacco litigation). By applying Boolean logic we were able to pull out relevant documents for more detailed examination. Altogether some 4000 pages were printed and analysed in detail.

The documents covered concentrate on the 1980s and early 1990s when the major tobacco control issues in Finland concerned public opinion on smoking, proposed restrictions on smoking, the level and structure of tobacco taxation, sales promotion, and the ongoing product liability litigation.

The problem with the documents is that they have not been indexed to files or folders according to dates or topics. Many documents have references to earlier correspondence and attachments, which cannot be found from the databases. The documents include internal codes and abbreviations, whose full meaning is difficult or impossible to interpret, and many of them are partially or totally smudged. On several occasions Finnish names have been misspelled and Scandinavian characters have been translated in different ways in the index field, which makes the research even more complicated. However, a document found with one search word often gives hints for new search words and they, again, may include further search words.

It is also very important to note that the documents have a shortcoming in exposing the course of events. Due to defects in filing, it is impossible to distinguish plans from implemented decisions, for example. Despite the limitations, the documents reflect the attitudes and policies of the industry. The documents are authentic in the sense that the persons who wrote them could hardly have imagined that their documents would one day become public. Thus these documents provide a unique opportunity to follow the strategy of the tobacco industry in opposing regulation. Consequently, the activities of tobacco companies are becoming better known than any other globally operating industry. With these documents it is possible to describe, study, and understand the activities of multinational companies on global markets.

The method of examination was to follow paper trails and categorise the documents. The documents examined include memos, drafts, plans, instructions, agreements, receipts, and other correspondence. Although we searched all the industry websites, the majority of documents were located at the PM website (www.pmdocs.com), mainly because PM together with Amer-Tupakka has dominated the Finnish tobacco market. Unlike its rivals, PM was not a defendant in product liability litigation in Finland from 1988 to 2001. The ongoing litigation made the other companies keep a low profile in resisting tobacco control measures. ${ }^{11}$

The content of the documents can be divided into larger categories by emphasising particular cases ${ }^{8}{ }^{12}$ or tactics used on a general level. Salojee and Dagli, ${ }^{7}$ who have identified 14 tactics which the industry has used in opposing tobacco legislation, apply the latter method. In this context, tactics are defined as the actual ways in which the strategy is executed. The advantage of a case typing of documents is having the tactics within the decision making context. However, exposing cases requires either voluminous coverage or concentration on limited cases only. In the following, the aim is to create an overview of the strategy and tactics concerning Finland.

The categories presented by Salojee and Dagli have been constructed to assess the international activities of tobacco companies and they are not entirely suitable for describing the situation in Finland. For example, manipulation of the media has been of key importance in Finland. This is examined in connection with PR activities. Consultancy programmes and commissioned research are included as new categories of tobacco industry tactics.

\section{RESULTS}

\section{Finland, the high risk market}

In November $1986 \mathrm{~J}$ Bernard Robinson, who worked at the EEMA unit of PM in Lausanne, Switzerland, gave a speech with the title "ETS in Nordic countries", where he stated that the target of the company in the EEMA region was not only to extinguish "perennial firefights" but also to influence the tobacco agenda of governments and anti-smoking activists. ${ }^{13}$ According to Robinson, this was "particularly relevant in the Nordic countries as their anti-tobacco initiatives can produce ripple effects far beyond their boundaries". ${ }^{13}$ Robinson mentions the fact that tobacco activists used the Nordic countries as an example when lobbying successfully for warnings in tobacco advertisements and on packs of cigarettes in the USA in 1983 and $1984 .{ }^{14}$ Robinson argued that the tobacco industry's historical reluctance to confront opponents in the Nordic region limited its credibility and reduced its willingness to influence events, and therefore the opponents had been able to secure adverse legislation that can lead the way for other markets.

In 1972, a letter sent to the Finnish Ministry of Social Affairs and Health by the Advisory Board on Tobacco pointed out that cigarette smoke in indoor air could be hazardous to the health of non-smokers, especially those with heart disease, allergies, or asthma. ${ }^{15}$ However, provisions concerning this were not included in the Tobacco Act of 1977, which was otherwise the most exhaustive in Europe. ${ }^{16}$

The high risk nature of the Finnish market was also characterised by the fact that Finland was a country without a history of consumer activism and a country where people were accustomed to paternalistic governance. ${ }^{17}$ The major enemy of the tobacco industry in Finland was the National Board of Health, which was believed to have an established goal of a smoke-free society. As evidence on the harmful effects of ETS began to mount, the health authorities and 
non-governmental organisations embarked on an intensive health promotion scheme to introduce smoking bans in public premises and workplaces. Because of these factors, Finland was counted among the high risk markets. ${ }^{18}$ Tobacco companies considered Finland even more dangerous than Sweden, where the state owned the biggest tobacco company in the country, the Swedish Tobacco Company. ${ }^{19}$

ETS was not the only concern. The importance of Finland as a market area is highlighted by an incidence where the CEO of PM, Geoffrey Bible, asked his staff to update him on the development of class action legislation in Finland. ${ }^{20} \mathrm{PM}$ feared that Finland, together with Sweden where similar legislation was being discussed, would introduce new tobacco control initiatives and push for them in the European Union $(\mathrm{EU}) .^{21}$

\section{Lobbying}

Before the mid 1980s, PM argued that the Nordic market was characterised by a lack of coordinated lobbying activity. The threat of ETS, together with new initiatives to introduce tobacco restrictions, brought the local tobacco manufacturers together. $^{22}$ The idea was to strengthen the National Manufacturers Associations (NMAs) in each market in order to combat tobacco control initiatives. ${ }^{23}$

\section{"Motivated by the deteriorating ETS trend, the industry has organised for the first time a Nordic NMA Working Group to address the ETS issue. Competitors and our business partners are hiring corporate affairs staff specialists and are reviewing plans to strengthen the NMAs in each market. ${ }^{\prime 24}$}

After the first Nordic working meeting, the PM Nordic Area report states as the prime objectives of NMA: (1) to counter the threat of further regulatory measures that will restrict market freedoms: (2) to re-establish smokers' self-esteem and the social acceptability of smoking: (3) to develop a strategy to protect the interests of PM in the event of a proposal to change the tax legislation; and finally (4) to build corporate affairs capabilities, and ally networks in the area. ${ }^{22}$

The first challenge concerned a proposition to harmonise tobacco legislation in the Nordic countries. The initiative was made by Iceland in 1987 at the Nordic Council, and one of its main objectives was to issue a total ban on tobacco advertising. ${ }^{25}$ To counter the adverse proposal within the Nordic Council, PM started to work with Amer-Tupakka to guide and support the lobbying activities of the local manufacturers against the Nordic Council. ${ }^{26}$ Allies were sought among media owners associations, advertisers, and employer federations. ${ }^{27}$

Finnair, the national airline in Finland, was the first airline in the world to introduce smoking and non-smoking sections on flights in the 1950s. In 1988, Finnair gave the first indications that it would ban smoking on all domestic flights and impose further restrictions pending a search for more factual information. At this stage, Amer-Tupakka pushed for negotiations with Finnair management to persuade them to allow in-flight air quality tests (IFAQ).$^{28}$ The ultimate goal of this activity was to make the airline adopt policies that would permit smoking during flights. In case Finnair refused to participate, an internal memorandum proposed an alternative tactic called "market research". ${ }^{29}$ It included a direct mail campaign to stimulate letters, postcards, and telephone calls urging Finnair to drop a total smoking ban.

In 1987, lobbying was also activated to oppose a government plan to reform the excise tax on tobacco. The idea was to utilise the personal contacts of the CEO of the Amer Group and the manager of a communications office, BNL, which operated as a subcontractor for PM, with the Minister of Finance. $^{30}$ The CEO of the Amer Group tried to lobby the minister by inviting him to a meeting and reserving a seat on the same flight to New York. ${ }^{31} 32$

In 1990, the tobacco companies found that the Ministry of Social Affairs and Health had drafted a proposal for a new tobacco act in autumn $1990 . .^{33}$ The proposal reached the government but never came before parliament. ${ }^{34}$ In March 1992, Amer-Tupakka discovered that the bill had been revived. ${ }^{34}{ }^{35}$ Amer-Tupakka had received the proposal "under the counter" - that is, before it became public, and sent it to its legal and medical experts. ${ }^{36}{ }^{37}$ Thus, the industry was able to launch a major lobbying effort to counter the proposal before it was even released. PM wanted to build a wide network of allies with a self-interest in opposing at least parts of the proposal. Targeted briefings with key politicians, political parties, authorities, and unions were to be carried out. The corporate affairs plan stated:

\section{"Raise valid and sufficient doubt concerning the applic- ability/legality of parts of the proposal, thus delaying the process and gaining time for continued ally building and

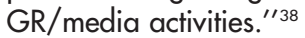

Among other things, PM planned to establish direct contact with the Minister of Social Affairs and Health and his chief advisor. The role of Amer-Tupakka was to take up direct MP briefings and encourage possible opposition if the bill were to reach parliament. Amer-Tupakka had close contacts with the chief secretary of the Ministry of Social Affairs and Health. ${ }^{39}$

The task of the senior vice president of corporate affairs at Amer-Tupakka was to lobby representatives of the Finnish trade organisations (notably SAK, the Central Organisation of Finnish Trade Unions, Liiketyönantajain keskusliitto LTK (currently the Employers' Confederation of Service Industries), and TKL, the Confederation of Finnish Industry and Employers), which are key players in formulating and winning support for social legislation in Finland. Somewhat earlier, the leaders of these organisations were on a PM VIP trip to Switzerland in order to create closer ties with leading Finnish union representatives and introduce guests to workplace smoking issues. ${ }^{40}$

SAK had initially taken a positive view of the new bill, because it considered tobacco smoke as a carcinogen..$^{33}$ After briefings with tobacco industry representatives, however, SAK was willing to change its position. In fact, SAK and the TKL together issued a statement that smoking in the workplace was an internal question for the working community, and did not need to be addressed by the authorities.

The senior vice president of corporate affairs at AmerTupakka had discussed the bill with the editor-in-chief of Ilta-Sanomat, a leading evening paper. ${ }^{33}$ After the briefing the editor-in-chief wrote a column strongly criticising the bill. It was also the senior vice presidents' job to get in touch with the Minister of Social Affairs and Health and advise him about the opinions of the tobacco industry relating to the newly released report by the US Environmental Protection Agency (EPA). ${ }^{41}$ The senior vice president was on holiday in the same area as the minister where they both had summer cottages. The minister had stated a paper had just arrived on his desk saying that a revolutionary new survey on ETS has come out in the USA and that authorities there were placing tobacco smoke on the list of carcinogenic substances. PM believed that the lobbyist from Amer-Tupakka would have had "extremely good opportunities"41 to brief the minister over the holiday period. He was supplied with a to-the-point 
package on the ETS/EPA draft risk assessment giving the message that there was no new study in the USA, that EPA is not a decision-making body, and that "the science has not changed". ${ }^{41}$

In 1995, PM invited one of the president's advisors to visit PM headquarters in New York. The object of the visit was to attend a briefing on tort reform and the class action process in the USA. ${ }^{42}$ To make sure that class action legislation would not be passed in Finland, PM planned to encourage resistance from the Ministry of Justice by targeting other ministers and government party politicians who might support the minister of justice who was against the bill. The intention was to brief and advise these parties directly or via allies. ${ }^{43} 44$

PM had also shown interest in the employees of the tobacco laboratory at the Technical Research Centre of Finland, which monitored maximum limits of harmful substances in tobacco products. Documents contain numerous citations of communications with laboratory employees and descriptions of their character..$^{45-47}$ Trips were organised for them to Neuchâtel in Switzerland, where the European research and development unit of PM (science \& technology) was situated. ${ }^{48}$

The favour of interest groups was also courted by various "treats". Amer-Tupakka has, among other things, paid for trips to Formula One races by politicians, labour union leaders, and journalists. For example, in 1992 trips to three different Formula One races were planned for those at government level. At the same time, trips to the Golf World Tour, sponsored by PM, were discussed. ${ }^{49}$ The goals of the programme were defined in an internal memo:

\section{"The GR (Government Relations) programme would continue to utilize the goodwill deriving from well arranged $\mathrm{Fl}$ and possible other PM sponsored events, while media relations would focus on further developing good contacts through well arranged and informative briefing trips and cultural events.... It was noted that contacts with Finnish authorities dealing with the European integration issues will be further developed and focused on. ${ }^{\prime \prime 4}$}

\section{Consultancy programme}

To win support for their view it was important for the tobacco companies to dominate the public debate on ETS. The aim was to confuse public opinion and attack the science on which the proposed regulations were based. However, this time their own research apparatus was no longer enough. PM and other companies decided to begin buying up experts throughout the world. The code name for the expert group was "Whitecoats". ${ }^{0}$ An internal memo by PM for Scandinavia and Finland describes the plan:

\section{"We will recruit consultants with political credibility, experts in welfare economics \& additional ETS whitecoats in Scandinavia/Finland." 50}

The purpose of the operation was to hire a group of researchers as consultants who would carry out research, write articles, give interviews, and participate in conferences. Law firms and proprietary research centres were also used to aid the experts. ${ }^{51}$ The aim of the programme was stated as follows:

"Work closely with S\&T (the research center of PM in
Switzerland) and John Rupp of Covington and Burling (a firm of lawyers) to complete the first phase of recruiting and activating the Nordic ETS whitecoats. Support their efforts to drive the thinking of their colleagues via articles and comments in the scientific literature and through presentations during symposia. Develop their ability to testify persuasively in government hearings and to generate positive stories in the popular press. ${ }^{\prime 51}$

In Finland, experts were planned to be recruited and trained to operate as credible third party spokesmen in environmental toxicology and ETS. ${ }^{52}$ The association of Nordic tobacco manufacturers discussed establishing an expert group in September 1987 and gave the go-ahead to the project. The Egil group (Expertgruppen för riskbedömning av inneluftens hälsorisker, a group of specialist on ETS health risks) was led by a Swedish doctor (who was also the president of the European Toxicology Association). Soon he had about 10 medical doctors available from different Nordic countries. ${ }^{53}$ Financing was channelled through a consulting company owned by the Swedish medical doctor which sent the invoices to London lawyers Covington \& Burling, who in turn invoiced PM.

One medical doctor from Finland, Olof Selroos, participated in Egil's activities. Selroos carried out an epidemiological study of respiratory parameters and smoke exposure as measured both by questionnaire and nicotine-in-hair analysis. At an Egil meeting in 1991 the doctor reported preliminary results which showed no correlation between hair nicotine and respiratory parameters, while a weak rank correlation was seen between hair nicotine and questionnaire responses..$^{54-56}$

A Finnish professor of pathology, Kari Syrjänen, carried out an extensive study on biological behaviour of genital human papilloma virus infections and their association with cancer. The project, which was started in 1990, was financed jointly by PM and BAT. ${ }^{57}$ The project had huge potential: it tried to prove that a virus was a major cause of cancer. Also, a former employee of the tobacco laboratory of the Technical Research Centre of Finland worked as a consultant for PM in product control matters. ${ }^{58-60}$

In April 1989, a Finnish professor of medicine wrote his Swedish colleague a letter in which he mentioned by name three doctors who he believed would agree to be consultants for Reynolds. ${ }^{61}$ In the end, only one of them consented to cooperation, when he assessed $\mathrm{x}$ ray pictures in relation to a lawsuit.

In connection with the preparation of the Tobacco Act, Amer-Tupakka used medical and legal consultants. A clinical chemist wrote a comprehensive report for Amer-Tupakka, attacking studies showing hazards caused by ETS. ${ }^{62}$ An internal memo considered how the doctor in question could most credibly be presented as an independent critic of the hazards caused by ETS. ${ }^{63}$ An associate professor of law wrote a report intervening among other things in the extent of the proposed advertising ban. ${ }^{64}$

\section{Paid research}

Commissioned research was used to support lobbying and to mould public opinion on ETS. ${ }^{65}$ In 1987, PM had a survey carried out in Finland, Sweden, and Norway, which aimed to show that most employees and employers would prefer to decide for themselves on smoking rules without government intervention. ${ }^{66}$ The costs of the study were shared within the NMAs ${ }^{67}$ The industry marketed the results though the media and their allies as part of a lobbying effort against smoking restrictions. The project was continued in Finland in June 1992 as an evening paper Ilta-Sanomat carried out and published an opinion poll at the instigation of Amer-Tupakka, 
which showed that most Finns were against governmental regulation of workplace smoking. ${ }^{68}$

PM internal correspondence demonstrates that the company has also financed research intending to prove the social advantages of smoking and the social disadvantages of tobacco taxation. ${ }^{69}{ }^{70}$ The purpose of these research projects was to prevent the introduction of further increases in tobacco taxation in the Nordic countries. ${ }^{69}$ In the late 1980s, a researcher who worked at the Helsinki School of Economics, wrote scientific articles in cooperation with PM on the costs to the public sector economy caused by smokers and nonsmokers and the regressiveness of tobacco tax-in other words, that the poor would pay more tobacco taxes than the rich. PM's own experts commented on the drafts and a Finnish consulting agency was hired to look for publication channels.

In 1988, Amer-Tupakka hired the Business Research Centre (LTT) in Finland to draw up an account of the social costs of tobacco. ${ }^{71}$ However, PM was not satisfied with the preliminary result, and insisted on essential amendments to the report. PM wanted to make smoking look more inexpensive to society than the preliminary results showed. At first, the LTT was against amendments stating that "breaking away from existing literature, which is dominated by anti-smoking views, demands to some extent courage" ${ }^{\prime \prime} .^{72}$ The problem was that the expert used by the LTT did not agree to change his calculations. After negotiations the LTT was ready to make amendments in exchange for an extra bonus. $^{73}$

PM also campaigned to show that there were agents other than tobacco smoke responsible for poor indoor air quality. The strategy was spelled out in PM's action plan for the Nordic countries in 1987: "move the discussion away from an ETS, to an Air Quality issue". ${ }^{74}$ Grey Robertson's company, Healthy Buildings International (HBI), specialised in the quality of indoor air and conducted research on ventilation systems. Through a Washington based law firm, the tobacco industry paid Robertson for conducting investigations on buildings, consultation, magazine publication, and even for lecture tours and meetings with journalists. Robertson's message was that individual sources of air impurity (such as tobacco smoke) were not the cause for substandard indoor air-the culprit was poor ventilation. Robertson distributed information worldwide on the so-called "sick building syndrome".

In Finland, HBI sought to conduct studies of indoor climate in the most prestigious buildings available. Apparently the purpose was to lend credibility and authority to Robertson's ideas. The sites studied included two Bank of Finland buildings and the City Hall in Espoo. ${ }^{75}$ Robertson appeared in the Finnish media as an expert on the quality of indoor air. $^{76}$ In the early 1990s, Roberson's publication Healthy Buildings International Magazine was published in Finland as an insertion in Talouselämä, a prestigious business weekly. ${ }^{77}$

\section{Intelligence gathering}

To gain more information and supplement services offered by INFOTAB ${ }^{78}$ tobacco companies hired communications agencies to gather information in Finland. Subcontractors assisted the industry in translating clippings and other published material and in identifying relevant research and decision makers. In the late 1980s, a business communications agency, BNL, helped PM to identify persons deciding about tobacco issues in Finland and in other Nordic countries by carrying out a survey on the main tobacco decision makers in the cabinets of the Nordic countries. ${ }^{79}$ In 1986, the same agency was assigned to study the National Board of Heath, its members, and its political relationships in order to identify ways and means of influencing the board. ${ }^{80}$ An internal memorandum suggests that PM also monitored the ETS conference at Hanasaari in mid June 1987 organised by the Nordic Institute of Advanced Occupational Environment Studies (NIVA). ${ }^{81}$

As a result of this intelligence gathering, the Finnish representatives of PM were able to report to PM headquarters that the Finnish National Board of Health was intending to demand that ingredient lists be attached to tobacco products at the end of $1988 .{ }^{82}$ At the same time, the Surgeon General in the USA was expected to publish a report on the ingredients of tobacco products. These two pieces of news led to a strategic recommendation. Instructions were given to PM's international and US organisations that they must collaborate in media strategy.

\section{"Developments on this issue in Finland could exacerbate the communication challenge in other markets, including the USA.... It's critical that the strategy be coordinated between PMI (Philip Morris International) and PM USA."}

PM headquarters were immediately informed if the statements of the Finnish partner did not please the company. The newly nominated CEO of Amer-Tupakka surprisingly admitted-in an interview in the leading daily newspaper Helsingin Sanomat in January 1990 - that tobacco causes cancer. ${ }^{83}$ The CEO withdrew his statement but was eventually forced to resign. Dozens of articles published about the matter were translated into English and sent to the directors of PM. The importance of the "slip" was emphasised by the fact that PM had earlier paid attention to the newspaper statements made by Amer-Tupakka. A local production manager of Amer-Tupakka stated in a newspaper article that the only way to avoid all the hazardous influences of smoking was to quit smoking and that all the methods of making tobacco less hazardous had been used up. ${ }^{84} \mathrm{PM}$ approached the CEO of Amer-Tupakka, in May 1987:

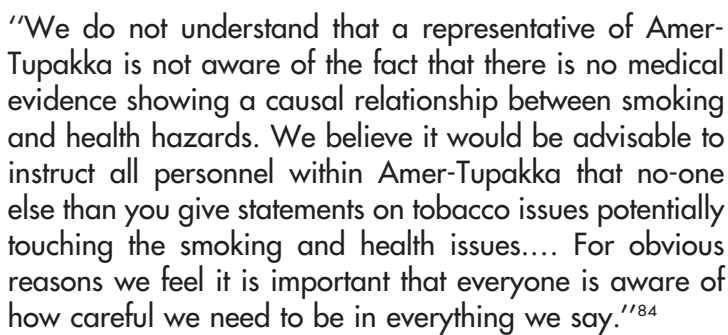

Finland's strategic position was evident by the fact that the companies used extensive resources to monitor local debate. The PM databases contain an amazing number of documents that are translations of Finnish proposals for legislation, publications, and press clippings. Many of the translated documents deal with the activities of people and organisations that were considered adversaries by the tobacco company. ${ }^{85} 86$ These included both health officials and representatives of non-governmental organisations, as well as doctors who pressed for smoking regulation and plaintiff lawyers in tobacco litigation.

\section{Public relations}

Journalists sympathetic to the tobacco industry provided fertile ground for the arguments of the tobacco companies, which claimed that the health effects of smoking were not proven and thus no regulation was warranted. The industry also wanted to produce stories that would bring attention to the role of the industry in the community, together with the history of tobacco and tobacco farming. ${ }^{87}$ The tactics were 
aimed at key players in the Finnish media-journalists who worked for leading newspapers (business newspaper Kauppalehti and evening paper Ilta-Sanomat) and some political newspapers (Demari, the newspaper published by the social democratic party), together with the only two national TV channels (MTV3 and YLE, the government owned TV channel).

Media tours were planned to be used as tools to deepen the personal contacts with a group of certain hand picked Nordic journalists, who had shown "an open mind". ${ }^{87}$ The most positive ones were to be invited to ETS briefing trips at Neuchâtel. ${ }^{87}$ The Nordic media coordinator of PM wrote in 1990:

\section{"We must have an up-to-date fact bank on the journalists who have attended our briefings, luncheons and ETS trips. We need to know their special interests, what they wrote etc.... Based upon this we will then put in place a follow-up system, including mailing, personal calls, meetings, and eventually new joint projects. ${ }^{\prime \prime 87}$}

In 1989, PM together with Amer-Tupakka had five Finnish journalists flown to the USA. ${ }^{88}$ This resulted in "a lot of positive publicity" ${ }^{88}$ The follow up effort with the journalists produced major articles where Amer-Tupakka was able to incorporate its own view about the cancer risks of tobacco and tobacco taxation. That helped to defeat the tax increase proposal by the Minister of Finance. In 1990, five Finnish journalists, representatives of Kauppalehti, the leading business newspaper, and Suomen Kuvalehti, the leading news magazine among them, took part in a Neuchâtel briefing for Nordic journalists. ${ }^{89}$

In anticipation of an ETS/EPA release in 1992, PM planned a communication campaign to balance the public discussion on the issue and to prevent the use of the ETS/EPA release as a tool for further smoking restrictions. ${ }^{90}$ Tactics included arranging efficient ETS/EPA spokesperson training for designated Amer-Tupakka spokespersons and arranging ETS/EPA media briefings for selected US based Finnish journalists. Finland was considered a special case due to ongoing tobacco litigation.

"It was noted that in all ETS/EPA communications in Finland the current very special Finnish circumstances need to be taken into consideration. There are indications for example that Rettig/STOY [local tobacco manufacturers] are not willing to comment much on the EPA report because of the pending legal cases. Therefore Finland would be the Nordic priority market for EPA Journalist briefings taking place by PM in the U.S."

Again, while opposing proposed class action legislation in Finland in 1995, PM mobilised all its contacts. PM intended to "maintain, upgrade and widen existing networks of businesses, organisations, academics, politicians, lawyers and journalists". ${ }^{91}$ As a part of the tactics, PM wanted to portray the US class action as a menacing example for Finland. The PM action plan stated:

"In co-operation with PM NY [WWRA, Worldwide Regulatory Affairs] collect background information and develop relevant argumentation based on the U.S./ English/Canadian and Australian experiences on the effects and practical implications related to class action legislation and describing in concrete terms the misuse of the legal system. ${ }^{\prime \prime 92}$
PM lobbied a TV journalist from MTV3, a commercial TV station, to interview opponents of class action in Finland and supplied him with names and background material for his trip to the USA. ${ }^{92}$ PM also enabled another journalist (who was an ex-corporate affairs officer for Amer-Tupakka) to travel to the USA together with the TV journalist. ${ }^{93}$ Additionally, PM planned to encourage grass roots lettersto-the editor on the subject. PM also planned to continue encouraging media criticism of the proposal, however, avoiding the debate becoming saturated too early. ${ }^{94}$ Key journalists were also to be briefed.

As part of a more general strategy, top level journalist trips were planned to Zimbabwe/Malawi, New York, and Beverly Hills. ${ }^{95}$ In 1999, PM was very anxious about a visit by the Washington correspondent of YLE, the Finnish Broadcasting Company, who wanted to make a news item on tobacco farming. ${ }^{96-100}$ PM made arrangements to accommodate the journalist's wishes so that the interests of the company would be served. PM sponsored art exhibitions and ballet competitions. ${ }^{101}{ }^{102}$ Allies and guests, journalists among them, were invited to these occasions.

\section{Smokers' rights groups}

The Smokepeace movement supported the tobacco industry in promoting the "accommodation message" ${ }^{4}$ In 1987, an internal PM memo mentioned that one aim of their PR activity was to "support HEN-RY Courteous Smokers Association in Denmark and to organize like-minded groups in Finland and Sweden" ${ }^{103}$ An association called Courteous Smokers (Huomaavaiset tupakoitsijat, Hu-Tu) was established in Finland. The association managed to acquire prominent figureheads, including well known politicians. PM also tried to set up an authoritative "smokers' club" within the Finnish Parliament where tobacco industry directors would act as hosts and where first class guests would be invited as lecturers. ${ }^{104}$ According to an internal memo, business communications agency BNL was hired for this purpose.

With scientific assistance from S\&T Neuchâtel, $\mathrm{Hu}-\mathrm{Tu}$ attacked the World Health Organization anti-smoking programme in 1992. ${ }^{105}$ At the same time, PM discussed supporting $\mathrm{Hu}-\mathrm{Tu}$ in a campaign to recruit new members. ${ }^{106}$ Later, Finnish authorities forbade Amer-Tupakka's financial support to $\mathrm{Hu}-\mathrm{Tu}$ as a violation of the Tobacco Act.

\section{Creating alliances}

By including other parties in their lobbying, the tobacco companies tried to mobilise forces to oppose smoking restrictions. To win support from the labour unions, PM planned to advertise in their publications. ${ }^{107108}$ Money was budgeted for publishing the results of an opinion poll which was aimed to show that people would prefer local arrangements over national regulation in the workplace smoking issue. Cooperation was also sought to resist removing tobacco from the consumer price index and the pension index. ${ }^{109}$ This was a part of an effort to prevent any increase in tobacco taxation.

Cooperation with allies was considered to be the most important part of the strategy for attacking the Tobacco Act amendment in the early 1990s. ${ }^{110}$ To fight restrictions on workplace and restaurant smoking, PM planned to join forces with labour union representatives and the Hotel and Restaurant Association. ${ }^{111}$ A financial support campaign was considered for that purpose. PM also wanted to establish contacts with the Central Chamber of Commerce (CCC), the International Chamber of Commerce in Paris, the Patent Ombudsmens' Association, and the Advertising Association on the diversification issue. ${ }^{37}$ Contacts were also to be 
established with the SYKL, the confederation for small and medium sized businesses.

In order to prevent legislation on class action, the tobacco companies planned cooperation with the CCC, the Central Federation on Industries and Employers, and the Bank Association. ${ }^{112}$

\section{Intimidation}

Since 1988, tobacco companies have been defendants in lawsuits in Finland. In this position they accused the plaintiff of exploiting the trials. The companies claimed personal compensation for legal expenses from the plaintiff's attorneys. In the judgement given by the Helsinki Court of Appeal at the end of 1998, the plaintiff's attorneys were, exceptionally, made personally liable for legal expenses. The Supreme Court reversed the judgement. The companies tried to prevent marketing offences from being brought up by threatening to report an offence of malicious accusation. ${ }^{113}$

\section{Litigation (defying restrictions)}

Since advertising and sales promotion of tobacco was banned in Finland by the Tobacco Act of 1977, the tobacco companies operating in Finland have had hardly any means of competing for bigger market shares. The only way to reach Finnish consumers was to arrange sales promotion campaigns, which would be observed by the Finnish media. ${ }^{114}$ According to a PM director "the one who is most successful in getting this kind of exposure is also the one who is most likely to be successful on the market". ${ }^{114}$

One way to get round the advertising ban was to sponsor sports. A PM internal memo describes in detail sponsoring a Finnish yachtsman in the BOC Challenge Single-handed Race Around the World from 1986 to $1987 . .^{115} 116$ The idea of the project was that the boat would be named Belmont, after a tobacco brand. If this had not succeeded, the company might have dropped the project. That the whole project would be stopped as a violation of the Tobacco Act was identified as the biggest risk of the project. Therefore it was decided to keep the name of the boat secret as long as it remained in Finland.

The Belmont project raised vast public interest, but also protests. Health advocates accused PM of circumventing the tobacco legislation. A complaint was lodged with the Finnish Chancellor of Justice, the matter was raised at a meeting of the shareholders of Amer-Tupakka, and finally a conditional fine was imposed on Amer-Tupakka for distributing material on the Belmont brand. The Belmont project led to tightening of the advertising ban in the Tobacco Act of 1995.

\section{THE EFFECTS OF TOBACCO INDUSTRY TACTICS}

Decision making on tobacco issues involves a multitude of factors affecting the final outcomes. Therefore, it is very difficult to establish causal relationships between tobacco industry tactics and regulatory outcomes. In the following, we will only look at references where actors in the tobacco industry evaluate the success of their efforts themselves. These are not mentioned as establishing a causal relationship, but rather reflecting the way events were interpreted within the industry.

As early as 1975, a PM internal memorandum states that local staff in Finland were able to persuade the government of Finland to increase tobacco prices by only $6 \%$ through raising excise tax, while the planned increase was as high as $53 \% .{ }^{117}$ The lobbying was supported by the Central Labour Union which was against high tobacco prices. Again in 1984, an internal report summarising "the remarkable success" of PM lobbying efforts in Finland was distributed among the PM directors. ${ }^{118}$ The results were described by one PM director as "highly desirable from the point of view of maintaining market share, a favourable level of taxation, and averting a costly price war". ${ }^{119}$ The report also gave more general recommendations, which is a direct indication that the tactics devised for Finland can be quoted as example of what could be done in other markets:

"To achieve these results required careful planning and timing by PM EEMA over several months. It clearly demonstrates not only how a properly conceived public affairs strategy can be successful, but also how many varied factors must be accounted for in developing such a plan. I commend this report to you as an excellent example of what might be done in other markets where our industry is facing threats. ${ }^{\prime 119}$

A summary written in October 1989 states that PM managed to reduce the publicity of the WHO No Smoking Day. ${ }^{120}$ The same report says that PM succeeded in preventing the implementation of a proposed tax increase of $20 \%$ on tobacco. An internal memorandum dated September 1991 states that the Minister of Social Affairs and Health, as a result of the lobbying activity by Amer-Tupakka, halted the process and took the proposal for the tax increase aside for a week to study it before signing. ${ }^{121}$ A major success for PM was that through intensive lobbying it prevented class action legislation from being introduced in Finland. ${ }^{91} 9294$

However, as pointed out above, the proposal for a new Tobacco Act was the major issue in the Finnish market since the early 1990s. The first proposal was raised in the autumn of 1990. An internal document states that Amer-Tupakka/PM initiated a series of information activities which resulted in the bill reaching the government but never being put before Parliament. ${ }^{122}$ This was a triumph for the industry as it was able to halt the introduction of a major legislative reform.

Despite opposition by the industry the bill was kept alive. In March 1992, PM learned that the ministry was again preparing a new law proposal which was considered as "a very severe one" since it would among other things "delegate more powers to different supervising bodies, almost giving them full freedom to harass the industry", "effectively ban trademark diversifications", and "ban smoking in public places and workplaces where there are more than two people". ${ }^{123}$ Again the process was delayed. Due to AmerTupakka/PM information activities, the Ministry of Health decided in September to take a new look at the bill and its practical implications. ${ }^{122}$

The objective of PM was to "successfully counter the Ministry's plans". ${ }^{124}$ Despite the use of intensive lobbying and the other tactics described above, the tobacco industry did not manage to prevent the introduction of a new tobacco law. Rettig Ltd, one of the local tobacco manufacturers operating in the tobacco industry for 150 years, was sold to RJ Reynolds a year after the new tobacco law come into force. Within the industry it was claimed that the price of the deal was lowered by the fact that there was such a comprehensive tobacco law in the local market. ${ }^{125}$

\section{CONCLUSIONS}

The Act on Measures for the Restriction of Tobacco Smoking was passed unanimously in the Finnish Parliament in 1976. The Act was very progressive at the time and Finland became the model country in preventive measures. Europe's first product liability case against the tobacco industry was brought in Finland in 1988. Simultaneously with the case, the authorities began revising certain provisions of the Tobacco Act which were difficult to interpret and implement.

Finland has been of particular interest to tobacco companies because of the country's long experience with 


\section{What this paper adds}

Finland has offered the tobacco industry laboratory-like circumstances to find out how tobacco companies can get along with comprehensive legislation and influence its development. The Tobacco Act of 1977 was very progressive at the time, and Finland became the model country in preventive measures. Failures on the small Finnish market hardly have much effect on international sales. Instead, experiences gained in Finland indicate how to prevent threatening legislation elsewhere.

The tobacco companies utilised similar strategies in Finland as in other industrial markets to fight tobacco control legislation, the health advocacy movement, and litigation. These activities slowed down the development and implementation of the Tobacco Act in Finland. However, despite the extensive pressure, the industry was not able to prevent the most progressive Tobacco Act in Europe from being passed and coming into force in Finland, neither in 1977 nor in 1995 .

tobacco legislation. The fear of ETS was considered greatest in those markets where regulation of smoking has been in place for a long time. The tobacco companies feared that restrictions imposed in Finland might spread to other markets. Thus Finland has served as an important target for investigation and pressure for the tobacco companies, even though the Finnish tobacco market itself is fairly small.

Documents concerning Finland show that here, too, the tobacco companies have systematically sought to prevent tobacco legislation and to steer discussion away from the harmful effects of smoking. The general picture of Finnish parliamentarism is characterised by the strong role of both workers' and employers' organisations. Finnish industries have traditionally lobbied law makers through their organisations. This does not seem to have been the case with the tobacco companies, which have mainly acted on their own initiative. The documents indicate that the same strategy that has been used elsewhere has been exported to Finland and implemented in the local environment. Tobacco companies have attempted to hide behind apparently objective and independent scientists, research results, and actors in public debate. Financial and other links between these actors and the tobacco industry have not been revealed. Clearly the companies have utilised internationally coordinated strategy, which has been applied in the local business environment. The Finnish case adds to the common knowledge of the local application of a standard international strategy devised by the tobacco industry. Furthermore, there is some evidence that the tobacco companies have used Finland as a test-bed for collecting experiences on how to operate in a hostile environment and have delivered that knowledge to other markets.

Avoiding tax increases, preventing class action legislation and delaying the enactment of the new Tobacco Act were clear triumphs for the tobacco companies. However, when these outcomes are contrasted with more comprehensive legislative development, these examples turn out to be of little importance. In spite of fierce opposition from the tobacco companies, what was the most comprehensive tobacco act in Europe at the time was enacted in Finland and it came into force at the beginning of 1995. As the proposal for a new Tobacco Act was processed by parliament several restrictions were added to it. It seems that PM was successful in lobbying the government but not with parliament. The battle over tobacco restriction ended with a defeat for the tobacco companies.
One reason behind the failure was that the industry did not manage to win support from public opinion. Denying the heath hazards caused by tobacco in product liability litigation-while scientific evidence on the harmful effects of ETS was mounting-undermined the credibility of the industry. Instead, the tobacco companies managed to defend themselves successfully in the product liability lawsuit. The industry was acquitted by the Supreme Court in June 2001.

\section{ACKNOWLEDGEMENTS}

This work was supported by grants from the Kone Foundation and the Poikonen Foundation. I want to thank Yussuf Saloojee, Kristiina Patja, Mervi Hara, Pekka Hakkarainen, and two anonymous referees for their valuable comments.

\section{REFERENCES}

1 Korten DC. When corporations rule the world. London: Earthscan, 1997.

2 Martin H-P, Schuman H. Die Globalisierungsfalle. Der Angriff auf Demokratie und Wohlstand. Reinbek Bei Hamburg: Rowohlt, 1996.

3 Beck U. Was ist Globalisierung. Irrtümen des Globalismus-Antworten auf Globalisierung. Surkamp. Frankfurt am Main: Surkamp, 1997.

4 Dearlove JV, Bialous SA, Glantz SA. Tobacco industry manipulation of the hospitality industry to maintain smoking in public places. Tobacco Control 2002;11:94-104

5 Muggli M, Forster J, Hurt R, et al. The smoke you don't see: uncovering tobacco industry scientific strategies aimed against environmental tobacco smoke policies. Am J Public Health 2001:91:1419-23.

6 Neuman M, Bitton A, Glantz SA. Tobacco industry strategies for influencing European Community tobacco advertising legislation. Lancet 2002;359:1323-30.

7 Salojee Y, Dagli E. Tobacco industry tactics for resisting public policy on health. Bull WHO 2000;78:902-10.

8 World Health Organization. Tobacco company strategies to undermine tobacco control activities at the World Health Organization. Report for the Committee of Experts on Tobacco Industry Documents. Geneva: WHO, 2000.

9 Aurejärvi E. Tupakkateollisuus maksumieheksi. Vieraskynä. Helsingin Sanomat. 11 November 1998:(Tobacco industry to pay off).

10 Anon. How to access tobacco industry documents. Tobacco Control 2002; 11 (suppl I):i39.

11 Philip Morris. Background and Status on Aho Case Communications. Philip Morris. November 15, 1991. Accessed November 15, 2002. Bates No. 2501067170. http://tobaccodocuments.org/pm/2501067170-7172.html.

12 Hiilamo H. Kieltämisen ammattilaiset. Tupakkayhtiöiden strategiat tupakkalainsäädännön estämiseksi Suomessa. Jyväskylä: Suomen ASH ry ja Lääkärin sosiaalinen vastuu ry, 2001. (Manufacturing Doubt. Tobacco Companies' Strategies to Undermine Tobacco Regulation in Finland).

13 Robinson JB. ETS in the Nordic Countries. Philip Morris. November 14 1986. Accessed March 10, 2001. Bates No. 2501042307. http:// www.pmdocs.com/getallimg.asp?DOCID $=2501042306 / 2340$

14 Ibid. Bates No. 2501042314

15 KM 1973: 42. Tupakkatoimikunnan mietintö. (A letter given to the Finnish Ministry of Social Affairs and Health by the Advisory Board on Tobacco in 1972).

16 Rimpelä AH. Critical analysis of the Finnish Tobacco Act: implementation and legitimacy, 1977-89. Tobacco Control 1992;1:285-93.

17 Philip Morris. Project Sauna Status Report. Philip Morris. July 29, 1986. Accessed December 28, 2000. Bates No. 2501073738. http:// www.pmdocs.com/getallimg.asp?DOCID = 2501073738/3740

18 Carlson S. EEMA Corporate Affairs. Philip Morris. October 22, 1991. Accessed November 11, 2001. Bates No.2501205612. http:// www.pmdocs.com/getallimg.asp?DOCID $=2501205612 / 5616$

19 Robinson JB. ETS in the Nordic Countries. Philip Morris. November 14 1986. Accessed March 10, 2001. Bates No. 2501042327. http:// www.pmdocs.com/getallimg.asp?DOCID $=2501042306 / 2340$

20 Wall CR. Finland: Class Action Legislation. Philip Morris. April 18, 1995. Accessed September 27, 2002. Bates No. 2047709928. http:// tobaccodocuments.org/pm/2047709928.html

21 Philip Morris. Class Action Finland-Corporate Affairs Action Plan. March 17, 1995. Accessed September 27, 2002. Bates No. 2073344158. http:// www.pmdocs.com/getallimg.asp?DOCID = 2073344157/4163

22 Carlson SG. Monthly and Quarterly Status Report, Corporate Affairs, Nordic Area. Philip Morris. July 9, 1987. Accessed September 28, 2002. Bates No. 2501048623-8631. http://tobaccodocuments.org/pm/25010486238631.html

23 Philip Morris. Corporate Affairs Plan. Philip Morris. November 25, 1987. Accessed September 28, 2002. Bates No. 2501254722-4723. http:// tobaccodocuments.org/pm/2501254715-4723.html

24 lbid. Bates No. 2501254721

25 Carlson SG. Monthly and Quarterly Status Report, Corporate Affairs, Nordic Area. Philip Morris. July 9, 1987. Accessed September 28, 2002. Bates No. 2501048623. http://tobaccodocuments.org/pm/2501048623-8631.html

26 Philip Morris. Philip Morris Efta, Eastern Europe, Middle East, Africa (EEMA) Long Range Plan. 1987 (est.). Accessed September 28, 2002. Bates No. 2500064557. http://tobaccodocuments.org/pm/2500064478-4624.html

27 Ibid. Bates No. 2500064559 
28 Carlson SG, Pottorff M. In Flight Air Quality (IFAQ) Tests on Nordic-Based Airlines. Philip Morris. July 6, 1988 (est.). Accessed September 28, 2002. Bates No. 2501458507-851 1. http://tobaccodocuments.org/pm/ 2501458507-8511.html

29 Ibid. Bates No. 2501458508.

30 Philip Morris. Corporate Affairs Issues, Nordic Area. Philip Morris. Jan 1987 (est.). Accessed September 28, 2002. Bates No. 2501048638. http:// tobaccodocuments.org/pm/2501048634-8647.html

31 Bernmark C Carlson SG. Quarterly Status Report, Corporate Affairs, Nordic Area. Philip Morris. July 1987. Accessed Semptember 28, 2002. Bates No. 2501048613. http://tobaccodocuments.org/pm/2501048609-8619.htm

32 Carlson SG. Meeting. Philip Morris. March 4, 1988. Accessed September 28, 2002. Bates No. 2501073578. http://tobaccodocuments.org/pm/ 2501073578-3579.html

33 Philip Morris. A Priorities, Status Report and Action Plan. Philip Morris. October 15, 1992. Accessed September 28, 2002. Bates No. 2501362182 2184. http://tobaccodocuments.org/pm/2501362175-2188

34 Philip Morris. Corporate Affairs, Nordic Area. Philip Morris. August 26, 1992. Accessed September 28, 2002. Bates No. 2501042038. http:// tobaccodocuments.org/pm/2501042037-2044.html

35 Philip Morris. A Priorities, Status Report and Action Plan. Philip Morris. October 15, 1992. Accessed September 28, 2002. Bates No. 25013621802181. http://tobaccodocuments.org/pm/2501362175-2188

36 Puotila J. Tobacco Act Amendment/Finland. Philip Morris. March 20, 1992. Accessed Semptember 28, 2002. Bates No. 2501236805-36807. http:// tobaccodocuments.org/pm/2501236805-6807.html

37 Philip Morris. Corporate Affairs, Nordic Area. Philip Morris. August 26 , 1992. Accessed September 28, 2002. Bates No. 2501042037. http:// tobaccodocuments.org/pm/2501042037-2044.html

38 Tupakkateollisuus sai salaiset asiakirjat. Tietovuotoa jäljitetään ministeriössä. Iltalehti July 1, 1993. (Tobacco industry got secret documents. The source of the leak is investigated at the ministry).

39 Kauniskangas K. Meeting with Mr. Hertzen. Philip Morris. February 22 1991. Access Data September 28, 2002. Bates No. 2047634364-4565. http://www.pmdocs.com/getallimg.asp?DOCID = 2047634364/4565

40 Puotila J. Vip/Customer Visit to Switzerland. Philip Morris. December 2 1991. Accessed September 28, 2002. Bates No. 2028364937. http:// tobaccodocuments.org/pm/2028364937.html

41 Puotila J. Epa/Finland. Philip Morris. June 29, 1992. Accessed September 28, 2002. Bates No. $2501236782 \mathrm{C}-2501236783$. http:// tobaccodocuments.org/pm/2501236782C-6783

42 Tricorache P. Media trip. Philip Morris. February 22, 1996. Accessed October 4, 2002. Bates No. 2046304868-4869. http:// www.pmdocs.com/getallimg.asp?DOCID = 2046304868/4869

43 Philip Morris. Class Action Finland. Corporate Affairs Action Plan. Philip Morris. December 15, 1995. Accessed September 28, 2002. Bates No. 2073344166. http://www.pmdocs.com/ getallimg.asp?DOCID = 2073344164/4169

44 Philip Morris. Class Action Finland. Corporate Affairs Action Plan. Philip Morris. March 17, 1995. Accessed September 28, 2002. Bates No. 2073344160. hittp://www.pmdocs.com/ getallimg.asp?DOCID = 2073344157/4163

45 Gaisch HW. Monthly Report Highlights, Fabriques De Tabac Reunies S.A. Philip Morris. August 31, 1987. Accessed Semptember 28, 2002. Bates No. 2001160791. http://tobaccodocuments.org/pm/2001160781-0791

46 Gaisch HW. Monthly Report Highlights, Fabriques De Tabac Reunies S.A. Philip Morris. March 31, 1987. Accessed September 28, 2002. Bates No. 2022151301-1302. http://tobaccodocuments.org/pm/20221512961314

47 Gaisch HW. Monthly Report Highlight, Fabriques De Tabac Reunies S.A. Philip Morris. December 23, 1988. Accessed September 28, 2002. Bates No. 2501152062. http://tobaccodocuments.org/pm/2501152054-2064

48 Gaisch HW. Monthly Report Highlights, FTR Science + Technology. Philip Morris. March 31, 1987. Accessed September 28, 2002. Bates No. 2001209243. http://tobaccodocuments.org/pm/2001 209236-9255.html

49 Philip Morris. Minutes of the Philip Morris/Amer CA Meeting. Philip Morris January 13, 1992. Accessed September 28, 2002. Bates No. 25010672947295. http://tobaccodocuments.org/pm/2501067291-7295.html

50 Philip Morris. Corporate Affairs Plan. Philip Morris. November 25, 1987. Accessed September 28, 2002. Bates No. 2501254715. http:// tobaccodocuments.org/pm/2501254715-4723.html

51 Pottorff M. PM EEMA Region: 1987 ETS Plan. Philip Morris. March 9, 1987. Accessed September 9, 2000. Bates No. 2023455038. http:// www.pmdocs.com/getallimg.asp?DOCID = 2023544027/4039

52 lbid. Bates No. 2023455029.

53 Thoma W. Remarks by Walter Thoma PMI Corporate Affairs Conference Boca Raton, Florida. Philip Morris. November 30, 1988. Accessed September 28, 2002. Bates No. 2501260741-0742. http:// tobaccodocuments.org/pm/2501260730-0745.html

54 Gaisch HW. Highlights August 1991. FTR Science and Technology. Philip Morris. August 30, 1991. Accessed September 21, 2000. Bates No. 2021599175. http://www.pmdocs.com/ getallimg.asp?DOCID = 2021599165/9175

55 Philip Morris. Corporate Affairs Plan. November 25, 1987. Accessed September 25, 2000. Bates No. 2501254722. http://www.pmdocs.com/ getallimg.asp?DOCID = 2501254715/4723

56 Philip Morris. ETS Strategy and Action Plans. Philip Morris. 1987. Accessed October 10, 2000. Bates No. 2028364825. hitp://www.pmdocs.com/ getallimg.asp?DOCID $=2028364825$

57 Philip Morris. Biological behaviour of genital human papilloma virus infections and their association with cancer. Philip Morris. August 22, 1994.
Accessed September 7, 2000. Bates No. 2063654300. http:// www.pmdocs. com/getallimg. asp?DOCID $=2063654300$

58 Gaisch HW. Monthly Report Highlights. Fabriques De Tabac Reunies S.A. Philip Morris. March 31, 1988. Accessed September 28, 2002. Bates No. 2001160644 . http://tobaccodocuments org/pm/2001160638-0650

59 Gaisch HW, Gygas J. Monthly Report Highlights, Fabriques De Tabac Reunies S.A. Philip Morris. June 30, 1989. Accessed September 28, 2002. Bates No. 2021599045. http://tobaccodocuments.org/pm/20215990379051

60 Gaisch HW, Marcovitch I. Monthly Report Highlights, Fabriques De Tabac Reunies S.A. Philip Morris. October 31, 1987. Accessed September 2002. Bates No. 2001160802 . hitp://tobaccodocuments.org/pm/20011607920806

61 Frick M. [A Letter to Åke Hjalmarson]. Philip Morris. April 10, 1989. Accessed October 19, 2002. Bates No. 2024961866. http:// tobaccodocuments.org/pm/2024961866.html

62 Hyvarinen A. Executive Summary. Philip Morris. February 17, 1993. Accessed September 28, 2002. Bates No. 2501012118-2140. http:// tobaccodocuments.org/pm/2501012118-2140.html

63 Andrade T. Facsimile Transmission Statement by Dr. Aulis Hyvarinen in Opposition to Finnish Tobacco Act Amendments to Ban Public and Workplace Smoking. Philip Morris. February 18, 1993. Accessed September 2002. Bates No. 2501012117 . http://tobaccodocuments.org/ $\mathrm{pm} / 2501012117 . \mathrm{html}$

64 Puhakka P. Law Proposal/Draft Statement. Philip Morris. April 7, 1993. Accessed November 20, 2002. Bates No. 2501046424. http:// muw pmdocs.com/getallimg asp?DOCID $=2501046426 / 6427$

65 Philip Morris. Corporate Affairs Plan. Philip Morris. November 25, 1987. Accessed September 25, 2000. Bates No. 2501254722-4721. http:// www.pmdocs.com/getallimg.asp?DOCID $=2501254715 / 4723$

66 Ibid. Bates No. 2501254722.

67 Bernmark C, Carlson SG. Quarterly Status Report. Corporate Affairs, Nordic Area. Philip Morris. September 10, 1987. Accessed October 19, 2002. Bates No. 2501048612. http://tobaccodocuments.org/pm/25010486098619.html

68 Philip Morris. A Priorities, Status Report and Action Plan. Philip Morris. October 15, 1992. Accessed September 28, 2002. Bates No. 2501362181. http://tobaccodocuments.org/pm/2501362175-2188.html

69 Thoma W. Remarks by Walter Thoma PMI Corporate Affairs Conference Boca Raton, Florida. Philip Morris. November 30, 1988. Accessed September 28, 2002. Bates No. 2501260739. http:// tobaccodocuments.org/pm/2501260730-0745.html

70 Besques J. Finland-Research Projects. Philip Morris. January 5, 1990 Accessed September 28, 2002. Bates No. 2048909354-9355. http:// tobaccodocuments.org/pm/2048909354-9355.html

71 Lehtonen P, Granfelt J. Study of the economic consequences of smoking in Finland. Philip Morris. January 22, 1988. Accessed July 24, 2001. Bates No. 2048909047-9053. http://www.pmdocs.com/ getallimg.asp?DOCID = 2048909047/9053

72 Besques J. Finland-Research Projects. Philip Morris. January 5, 1990. Accessed July 24, 2001. Bates No. 2048909355. http:// tobaccodocuments.org/pm/2048909354-9355.html

73 Lehtonen P, Granfelt J. Study of the economic consequences of smoking in Finland. Philip Morris. January 19, 1990. Accessed July 24, 2001. Bates No. 2048909192-9193. http://www.pmdocs.com/ getallimg.asp?DOCID = 2048909192/9193

74 Philip Morris. Corporate Affairs Issues, Nordic Area. Philip Morris. Jan 1987 (est.). Bates No. 2501048642. http://tobaccodocuments.org/pm/ 2501048634-8647.htm

75 Philip Morris. ETS Strategy and Action Plans. Philip Morris. 1987. Accessed October 10, 2000. Bates No. 2028364825. http://www.pmdocs.com/ getallimg.asp?DOCID $=2028364825$

76 Carlson S. Healthy Buildings -88. Philip Morris. July 14, 1988. Accessed December 28, 2000. Bates No. 2501046489. http://www.pmdocs.com/ getallimg.asp?DOCID = 2501046489/6491

77 Robertson G. Invoice HBI Magazine Finland Issue Number 6. Philip Morris. November 15, 1991. Accessed September 28, 2002. Bates No. 2024526138. http://tobaccodocuments.org/pm/2024526138.htm

78 Yach D, Bettcher D. Globalisation of tobacco industry influence and new global responses. Tobacco Control 2000;9:206-16

79 Kannangara A. PM EEMA Region: 1987 ETS Plan. Philip Morris. March 9 1987. Accessed September 9, 2000. Bates No. 2023544031. http:// www.pmdocs.com/getallimg.asp?DOCID $=2023544027 / 4039$

80 Philip Morris. Project Sauna Status Report. Philip Morris. July 29, 1986. Accessed December 28, 2000. Bate No. 2501073740. http:// www.pmdocs.com/getallimg.asp?DOCID $=2501073738 / 3740$

81 Carlson SG. Monthly and Quarterly Status Report. Corporate Affairs. Nordic Area. Philip Morris. July 9 1987. Accessed December 28, 2000. Bates No. 2501048624. http://tobaccodocuments.org/pm/2501048623-8631.html

82 Robinson JB. GBS's 12/13/88 Memorandum-Item 11. Philip Morris. December 22, 1988. Accessed December 28, 2000. Bates No. 2022969993. http://tobaccodocuments.org/pm/2022969993-9994.html

83 livonen J. Amerin uusi toimitusjohtaja myöntää: Tupakka aiheuttaa syöpää. Helsingin Sanomat. January 9, 1990. Section D3. (The new CEO of Amer Admits: Tobacco causes cancer).

84 Weber G. Article in Turun Sanomat. Philip Morris. May 22, 1987. Accessed September 28, 2002. Bates No. 2501468546A-8547. http:// tobaccodocuments.org/pm/2501468546A-8547.html

85 Chydenius L. Wednesday Report. Philip Morris. March 20, 1988. Accessed November 4, 2000. Bates No. 2501040025-0028. http:// www.pmdocs.com/getallimg.asp?DOCID $=2501040025 / 0028$ 
86 Belli C, Linehan K. Eema Corporate Affairs Weekly Highlights. Philip Morris. October 25, 1996. Accessed September 28, 2002. Bates No. 20653933753376. http://tobaccodocuments.org/pm/2065393373-3376.html

87 Bonnier I. Journalist programme, Nordic Area. Second Draft. Philip Morris. August 2, 1990. Accessed September 28, 2002. Bates No. 2023590042. http://www.pmdocs.com/getallimg.asp?DOCID = 2023590040/0043

88 Farnel FJ. Eema Regional Annual Report Regarding PMI Corporate Affairs Action Plan. Philip Morris. October 16, 1989. Accessed September 28, 2002. Bates No. 2500019976. http://tobaccodocuments.org/pm/ 2500019962-9976.html

89 Gaisch HW. FTP Science and Technology. Highligts December 21, 1990. Philip Morris. Accessed September 20, 2000. Bates No. 2028440688. http://www.pmdocs.com/getallimg.asp?DOCID = 2028440678/0689

90 Philip Morris. Minutes of the Philip Morris/Amer CA Meeting. Philip Morris. January 13, 1992. Accessed September 28, 2002. Bates No. 2501067293. $\mathrm{http}: / /$ tobaccodocuments.org/pm/2501067291-7295.html

91 Philip Morris. Class Action Finland. Corporate Affairs Action Plan. Philip Morris. December 15, 1995. Accessed September 28, 2002. Bates No. 2073344166. http://www.pmdocs.com/ getallimg.asp?DOCID = 2073344164/4169

92 Philip Morris. Class Action Finland. Corporate Affairs Action Plan. Philip Morris. March 17, 1995. Accessed September 28, 2002. Bates No. 2073344160. http://www.pmdocs.com/ getallimg.asp?DOCID = 2073344157/4163

93 Puotila J. Class Action/Finland. Philip Morris. August 25, 1995. Accessed September 28, 2002. Bates No. 2073344176. http://www.pmdocs.com/ getallimg.asp?DOCID = 2073344176/4177

94 Philip Morris. Class Action Finland Corporate Affairs Action Plan. Philip Morris. June 4, 1996. Bates No. 2073344174. Accessed September 28, 2002. http://www.pmdocs.com/getallimg.asp?DOCID = 2073344170/ 4175

95 Bonnier I. Journalist programme, Nordic Area. Second Draft. Philip Morris. August 2, 1990. Accessed September 28, 2002. Bates No. 2023590043. http://www.pmdocs.com/getallimg.asp?DOCID = 2023590040/0043

96 Puotila J. Re: Mr. Lindroos /Yle. Philip Morris. December 2, 1997. Accessed October 4, 2002. Bates No. 2072388893-8894. http:// tobaccodocuments.org/pm/2072388893A-8894.html

97 Daragan K. Re: Mr. Lindroos/Yle. Philip Morris. December 2, 1997. Accessed October 4, 2002. Bates No. 2072388894. http:// tobaccodocuments.org/pm/2072388894A.html

98 Puotila J. Re: Mr. Lindroos/Yle. Philip Morris. November 24, 1997. Accessed October 4, 2002. Bates No. 2072388899. http:// tobaccodocuments.org/pm/2072388899A.html

99 Ibid. Bates No. 2072388898.

100 Puotila J. Re: Mr. Lindroos/Yle. Philip Morris. December 2, 1997. Accessed October 4, 2002. Bates No. 2072388893A-8894. http:// tobaccodocuments.org/pm/2072388893A-8894.htm

101 Philip Morris. P.J. Minutes of the Philip Morris/Amer CA Meeting. Philip Morris. December 11, 1991. Accessed October 10, 2000. Bates No. 2501067294. http://www.pmdocs.com/ getallimg.asp?DOCID $=2501067291 / 7295$

102 Ibid. Bates No. 2501067291

103 Philip Morris. Corporate Affairs Plan. Philip Morris. November 25, 1987. Accessed September 25, 2000. Bates No. 2501254722. http:// www.pmdocs.com/getallimg asp?DOCID $=2501254715 / 4723$

104 Philip Morris. Corporate Affairs Issues, Nordic Area. Philip Morris. Jan 1987 (est.). Accessed September 28, 2002. Bates No. 2501048643. http://tobaccodocuments.org/pm/2501048634-8647.html

105 Gaisch HW. Executive Report of Activities S\&T Neuchatel. Philip Morris. February 1992. Accessed September 28, 2002. Bates No. 2501254595. http://tobaccodocuments.org/pm/2501254590-4597.html

106 Philip Morris. P.J. Minutes of the Philip Morris/Amer CA Meeting. Philip Morris. December 11, 1991. Accessed October 20, 2002. Bates No. 2501067294-7295. http://www.pmdocs.com/ getallimg. asp?DOCID $=2501067291 / 7295$
107 Carlson SG. Proposal for 2nd Step of Finnish 'eureca' Study Merchandising. Philip Morris. October 23, 1987. Accessed September 28, 2002. Bates No. 2501468559-8561. http://tobaccodocuments.org/pm/25014685598561. html

108 Bernmark C, Carlson SG. Quarterly Status Report, Corporate Affairs, Nordic Area. Philip Morris. July 1987. Accessed September 28, 2002. Bates No. 2501048611-8612. http://tobaccodocuments.org/pm/25010486098619.html

109 Thoma W. Remarks by Walter Thoma PMI Corporate Affairs Conference Boca Raton, Florida. Philip Morris. November 30, 1988. Accessed September 28, 2002. Bates No. 2501260740. http:// tobaccodocuments.org/pm/2501260730-0745.html

110 Puotila J. Corporate Affairs. Nordic Area. Philip Morris. August 26, 1992. Accessed October 20, 2002. Bates No. 2501042038-2039. http:// www.pmdocs.com/getallimg.asp?DOCID = 2501042037/2044

111 Philip Morris. P.J. Minutes of the Philip Morris/Amer CA Meeting. Philip Morris. December 11, 1991. Accessed October 10, 2000. Bates No. 2501067294. http://www.pmdocs.com/ getallimg.asp?DOCID = 2501067291/7295

112 Philip Morris. Class Action Finland. Corporate Affairs Action Plan. Philip Morris. December 15, 1995. Accessed September 28, 2002. Bates No. 2073344166-4167. http://www.pmdocs.com/ getallimg.asp?DOCID $=2073344164 / 4169$

113 Hiilamo H. Kieltämisen ammattilaiset. Tupakkayhtiöiden strategiat tupakkalainsäädännön estämiseksi Suomessa. Jyväskylä: Suomen ASH ry ja Lääkärin sosiaalinen vastuu ry, 200:30-31. (Manufacturing Doubt. Tobacco Companies' Strategies to Undermine Tobacco Regulation in Finland)

114 Weber G. The Belmont Sailing Promotion Finland. Philip Morris. July 16, 1985. Accessed November 10, 2000. http://www.pmdocs.com/ getallimg.asp? DOCID = 2501046541 /6547

115 Philip Morris. [Belmont Sponsoring Project Breafing]. Philip Morris. Accessed November 10, 2000. http://www.pmdocs.com/ getallimg.asp?DOCID $=2501046550 / 6572$

116 Philip Morris. Belmont Sponsoring Project. Philip Morris. Accessed November 10, 2000. http://www.pmdocs.com/ getallimg.asp? $\mathrm{DOCID}=2501046522 / 6540$

117 Isenring P. Finland-Smoking \& Health Advertising Restrictions. Philip Morris. May 22, 1975. Accessed October 20, 2002. Bates No. 1005145351. http://www.pmdocs.com/ getallimg.asp?DOCID = 1005145351/5354

118 Philip Morris. Cigarette Tax Change in Finland, 1993. Philip Morris. May 1984. Accessed August, 19, 2002. Bates No. 2073421602-1608. http:// www.pmdocs.com/getallimg.asp?DOCID = 2073421602/1609

119 Whist A. Tax Changes in Finland. Philip Morris. September 4, 1984 Accessed August, 19, 2002. Bates No. 20733421601. http:// www. pmdocs.com/getallimg asp?DOCID $=2073421601$

120 Farnel FJ. Eema Regional Annual Report Regarding PMI Corporate Affairs Action Plan. Philip Morris. October 16, 1989. Accessed October 19 2002. Bates No. 2500019975. http://tobaccodocuments.org/pm/ 2500019962-9976.htm

121 Philip Morris. [No title]. Philip Morris. September 13, 1991. Accessed September 28, 2002. Accessed September 28, 2002. Bates No. 2501009388. http://tobaccodocuments.org/pm/2501009388.html

122 Philip Morris. A Priorities, Status Report and Action Plan. Philip Morris. October 15, 1992. Accessed September 28, 2002. Bates No. 2501362180-2180. http://tobaccodocuments.org/pm/25013621752188. html

123 Puotila J. Tobacco Act Amendment/Finland. Philip Morris. March 20, 1992. Accessed September 28, 2002. Bates No. 2501236805-6807. http:// tobaccodocuments org/pm/2501236805-6807.html

124 Philip Morris. A Priorities, Status Report and Action Plan. Philip Morris. October 15, 1992. Accessed September 28, 2002. Bates No. 2501362182. $\mathrm{http}: / /$ tobaccodocuments.org/pm/2501362175-2188.html

125 Hakkarainen P. Tupakka-nautinnosta ongelmaksi. Tampere: Vastapaino, 2000:131. (Tobacco-from enjoyment to social problem). 